\title{
HUBUNGAN KARAKTERISTIK PETANI DENGAN ADOPSI INOVASI BIBIT KAKAO SAMBUNG PUCUK MCC 02
}

\author{
Relationship of Farmers' Characteristics with the Adoption of Cocoa \\ Breeding Innovation to Continue to MCC 02 \\ Taufiq Triadi $^{\left.{ }^{*}\right)}$, Safaruddin $^{2)}$, Syamsuddin $^{3)}$ \\ ${ }^{1)}$ Sekolah Pascasarjana, Institut Pertanian Bogor \\ ${ }^{23)}$ Program Studi Agribisnis, Fakultas Pertanian, Universitas Cokroaminoto Palopo \\ ${ }^{\left.{ }^{*}\right)}$ taufiqtriadi23@gmail.com
}

\begin{abstract}
ABSTRAK
Karakteristik petani dapat berhubungan dalam proses pengambilan keputusan dan penyerapan informasi dalam proses adopsi inovasi. Penelitian ini bertujuan untuk menganalisis hubungan karakteristik petani dengan adopsi inovasi bibit kakao sambung pucuk MCC 02. Penelitian ini dilaksanakan di Desa Tandung Kecamatan Sabbang Kabupaten Luwu Utara. Penelitian ini dilakukan dalam kurun waktu 4 bulan, dimulai pada bulan Februari hingga Mei tahun 2020. Desain penelitian ini adalah deskriptif korelasional dengan analisis terhadap semua indikator variabel dan hubungan antar variabel. Sampel yang digunakan adalah Kelompok Tani Limbong Dewata berjumlah 26 orang dan Kelompok Tani Rante Sipulung berjumlah 25 orang jadi total keseluruhan sebanyak 51 sampel. Hasil penelitian menunjukkan tingkat adopsi inovasi bibit kakao sambung pucuk MCC 02 didua kelompok yaitu kelompok tani Limbong Dewata dan kelompok tani Rante Sipulung masing-masing berada pada kategori tinggi. Karakteristik petani yang berhubungan dengan tingkat adopsi bibit adalah pengalaman usaha tani, sedangkan umur, pendidikan formal, pendidikan non formal luas lahan tidak berhubungan dengan tingkat adopsi bibit kakao sambung pucuk MCC 02.
\end{abstract}

\section{Kata kunci : adopsi inovasi, bibit kakao sambung pucuk MCC 02, karakteristik petani}

\begin{abstract}
Farmer characteristics can be related to the decision-making process and the absorption of information in the innovation adoption process. This study aims to analyze the relationship between farmer characteristics and adoption of MCC 02 shoot-grafting cocoa seed innovation. This research was conducted in Tandung Village, Sabbang District, North Luwu Regency. This research was conducted over a period of 4 months, starting from February to May 2020. The design of this research is descriptive correlation with analysis of all variable indicators and the relationship between variables. The sample used was the Limbong Dewata Farmer Group with 26 people and the Rante Sipulung Farmer Group with 25 people, so a total of 51 samples were used. The results showed that the adoption rate of MCC 02 shoot grafting innovation in two groups, namely the Limbong Dewata Farmer's Group and the Rante Sipulung Farmer's Group, were in the high category, respectively. Farmer characteristics related to the level of seed adoption are farming experience, while age, formal education, non-formal education, land area are not related to the adoption rate of shoot grafting cocoa seedlings MCC 02.
\end{abstract}

Keywords: innovation adoption, MCC 02 shoot grafting cocoa seeds, farmer characteristi

\section{PENDAHULUAN}

Kakao merupakan salah satu

komoditas unggulan dari subsektor

perkebunan yang berkontribusi secara signifikan dalam perekonomian di Luwu Utara. Produksi kakao di Luwu Utara mencapai 26.310,46 ton/tahun dengan luas lahan sebanyak 39.220,27 hektar sehingga 
Perbal: Jurnal Pertanian Berkelanjutan

Fakultas Pertanian Universitas Cokroaminoto Palopo

menjadikanya sentra pengembangan dan penghasil kakao terbesar di Provinsi Sulawesi Selatan ((BPS, 2019).

Perkembangan tanaman kakao di Kabupaten Luwu Utara dalam Beberapa tahun terakhir mengalami penurunan. Peningkatan luas lahan tidak seiring dengan peningkatan produksi. Dilihat pada tahun 2016-2017 mengalami peningkatan luas lahan dari dari 38.127,60 ke 39.410,07 namun produksi menurun dari 27.391,20 ton ke 26.310,46 ton, selanjutnya pada tahun 2018 produksinya stagnan (BPS, 2019).

Kecamatan Sabbang merupakan salah satu kecamatan produksi kakao terbesar di Luwu Utara sebanyak 6.146,30 ton/tahun dengan luas lahan 11.070,80 hektar pada tahun 2018 (BPS, 2019). Meskipun luas lahan beberapa tahun terakhir meningkat, namun tak sejalan dengan peningkatan produksi. Luas lahan Kecamatan Sabbang dalam kurun waktu 2014-2018 mengalami peningkatan dari 9.184,00 ke 11.070,80 hektar namun berbanding terbalik dengan produksi, dimana produksi kakao pada tahun 20142018 mengalami penurunan dari 9.006,00 ke 6.146,30 ton/tahun (BPS, 2019). Penurunan produksi kakao di Luwu Utara diakibatkan beberapa faktor mulai dari dari penggunaan bibit tidak unggul, kakao sudah tua, serta serangan hama dan penyakit. Sejalan dengan (Fairuzia, 2019) mengungkapkan bahwa faktor penyebab penurunan produksi kakao di Kabupaten Luwu Utara erat kaitannya dengan tanaman yang digunakan sudah tua, kakao terkena serangan hama dan penyakit, serta teknik budidaya pemeliharaan tanaman yang kurang maksimal.

Terkait dengan permasalahan penurunan produksi kakao di Luwu Utara maka dilakukan kegiatan peremajaan tanaman kakao komoditas perkebunan berkelanjutan di Kabupaten Luwu Utara pada Tahun 2018, dengan memberikan inovasi bibit sambung pucuk Masamba Cacao Clon (MCC) 02 kepada kelompok tani (Keputusan Bupati Luwu Utara No 188.4.4.45 /254/ IV /2018). Syakir (2016) mengatakan bahwa kunci utama dalam memberdayakan petani adalah melalui inovasi dan diseminasi teknologi, berbagai studi melaporkan bahwa inovasi terbukti telah menjadi sumber peningkatan produksi pertanian dan pendapatan pada petani. Namun beberapa hasil inovasi pertanian belum dimanfaatkan secara optimal oleh masyarakat. Menurut (Syakir, 2016) hasil penelitianya berpendapat bahwa banyak inovasi yang dihasilkan oleh Badan Litbang Pertanian belum diadopsi dengan baik dan 
pada skala luas, dikarenakan adanya hambatan pada penyampaian dan penerima sehingga menyebabkan lambannya penyampaian informasi dan rendahnya tingkat adopsi inovasi.

Penelitian terkait adopsi inovasi paket teknologi introduksi kakao pada kawasan perkebunan nasional di Sulawesi Barat, hasil penerapan inovasi teknologi pascapanen (fermentasi) untuk mutu biji kakao oleh anggota kelompok tani masih sangat rendah (Indrayana \& Syamsuddin, 2019). Adopsi inovasi merupakan suatu keputusan untuk menerapkan suatu hal baik berupa ide maupun teknologi. Dalam hal penerapan teknologi inovasi oleh petani umumnya penerimaan maupun penolakan pada umumnya didasari oleh karakteristik sosial ekonomi petani (Sitanggang et al., 2014).

Menurut (Rosyida et al., 2021) ada beberapa faktor yang menghambat atau memperlancar adopsi teknologi petani salah satunya dipengaruhi oleh faktor karakteristik sosial ekonomi petani mulai dari, usia petani, tingkat pendidikan, dan tingkat pendapatan petani. Hal ini seleras dengan hasil penelitian Indraningsih (2011); Manongko et al., (2017); Rosyida et al., (2021) hasil menujukkan bahwa karakteristik petani berhubungan secara signifikan dengan tingkat adopsi inovasi.

Karakteristik responden merupakan salah faktor yang penting diperhatikan dalam penerimaan suatu inovasi (Ahmad, 2016). Karakteristik petani dapat berhubungan dalam proses pengambilan keputusan dan penyerapan informasi dalam proses adopsi inovasi. berdasarkan pemaparan diatas menarik untuk diteliti mengenai hubungan antara karakteristik petani dengan adopsi inovasi bibit kakao sambung pucuk MCC 02. Maka dari itu tujuan dalam penelitian ini yaitu ingin melihat hubungan karakteristik petani dengan adopsi inovasi bibit kakao sambung pucuk MCC 02.

\section{METODE PENELITIAN}

Desain penelitian ini adalah deskriptif korelasional dengan analisis terhadap semua indikator variabel dan hubungan antar variabel. Penelitian ini dilakukan di Desa Tandung Kecamatan Sabbang, Kabupaten Luwu Utara Provinsi Sulawesi Selatan. Pengambilan lokasi penelitian dilakukan secara purposive dengan mempertimbangkan Kecamatan Sabbang merupakan penghasil kakao terbesar di Luwu Utara dan merupakan penerima bantuan bibit kakao kegiatan peremajaan tanaman kakao. Penelitian ini dilakukan dalam kurun waktu 4 bulan, 
Perbal: Jurnal Pertanian Berkelanjutan

Fakultas Pertanian Universitas Cokroaminoto Palopo

dimulai pada bulan Februari hingga Mei tahun 2020. Sampel yang digunakan adalah keseluruhan populasi Kelompok Tani Limbong Dewata berjumlah 26 orang dan Kelompok Tani Rante Sipulung berjumlah 25 orang jadi total keseluruhan sebanyak 51 sampel. Penelitian ini diawali dengan melakukan wawancara menggunakan instrumen kuesioner dan pengamatan (observasi). Kuesioner terdiri dari pertanyaan mengenai tingkat adopsi bibit kakao sambung pucuk MCC 02. Analisis data menggunakan analisis statistik deskriptif dan analisis uji korelasi Rank Spearman dengan aplikasi SPSS.

\section{HASIL DAN PEMBAHASAN}

Karakteristik responden yang digunakan dalam penelitian ini meliputi umur, pendidikan formal, pendidikan non formal, pengalaman usaha tani dan luas lahan. Berikut karakteristik sesuai dengan hasil pengolahan data penelitian.

Tabel 1. Persentase anggota Kelompok Tani Limbong Dewata dan Kelompok Tani Rante Sipulung berdasarkan karakteristik individu

\begin{tabular}{|c|c|c|c|c|c|}
\hline \multirow{2}{*}{ No } & \multirow{2}{*}{ Karakteristik Individu } & \multicolumn{2}{|c|}{ K I } & \multicolumn{2}{|c|}{ K II } \\
\hline & & Orang & $\%$ & Orang & $\%$ \\
\hline \multirow[t]{4}{*}{1} & Umur & & & & \\
\hline & Dewasa Awal & 6 & 23,1 & 3 & 12,0 \\
\hline & Dewasa Tengah & 8 & 30,7 & 9 & 36,0 \\
\hline & Dewasa Akhir & 12 & 46,2 & 13 & 52,0 \\
\hline \multirow[t]{5}{*}{2} & Pendidikan & & & & \\
\hline & Formal & & & & \\
\hline & Rendah (SD) & 14 & 53,8 & 17 & 68,0 \\
\hline & Sedang (SMP/SMA) & 8 & 30,8 & 7 & 28,0 \\
\hline & Tinggi (Sarjana) & 4 & 15,4 & 1 & 4,0 \\
\hline \multirow[t]{4}{*}{3} & Pendidikan Non Formal & & & & \\
\hline & Rendah & 2 & 7,7 & 1 & 4,0 \\
\hline & Sedang & 11 & 42,3 & 10 & 40,0 \\
\hline & Tinggi & 13 & 50,0 & 14 & 56,0 \\
\hline \multirow[t]{4}{*}{4} & Pengalaman Usaha Tani & & & & \\
\hline & Rendah & 7 & 26,9 & 7 & 28,0 \\
\hline & Sedang & 12 & 40,2 & 12 & 48,0 \\
\hline & Tinggi & 7 & 26,9 & 6 & 24,0 \\
\hline \multirow[t]{4}{*}{5} & Luas Lahan & & & & \\
\hline & Sempit (1 ha) & 4 & 15,4 & 8 & 32,0 \\
\hline & Sedang (2 ha) & 14 & 53,8 & 10 & 40,0 \\
\hline & Luas (3 ha) & 8 & 30,8 & 7 & 28,0 \\
\hline
\end{tabular}

Sumber: Hasil penelitian setelah diolah, 2020 
Karakteristik anggota kelompok tani dilihat dari umur anggota dibedakan atas tiga kategori, dimana kategori tersebut terdiri dari: (1) dewasa awal, yang berumur antara 26 sampai dengan 35 tahun (2) dewasa tengah 36 sampai 45 tahun, dan (3) Dewasa akhir yakni mereka yang berumur dari 46 sampai 55 tahun. Adapun komposisi anggota Kelompok Tani Limbong Dewata berdasarkan umur, mayoritas terdiri dari mereka yang tergolong ke dalam masa dewasa akhir 46 sampai 55 tahun dengan persentase sekitar 46,2 persen. Adapun persentase anggota kelompok tani yang tergolong ke dalam masa dewasa awal dan dewasa tengah berturut-turut sebesar 23,1 persen dan 30,8 persen. Sedangkan pada Kelompok Tani Rante Sipulung mayoritas terdiri dari mereka yang tergolong ke dalam masa masa dewasa akhir 46 sampai 55 dengan persentase sekitar 52,0 persen, selanjutnya kelompok tani yang tergolong ke dalam masa dewasa awal dan dewasa tengah berturut-turut sebesar 12,0 persen dan 36,0 persen

Tingginya persentase pada dua anggota kelompok tani yang tergolong dalam kategori masa dewasa akhir 46 sampai 55 berhubungan dengan fakta bahwa penduduk yang tergolong dalam usia muda lebih memilih bekerja pada sektor lain dibandingkan dengan berusahatani. Adapun kondisi ini didukung oleh fakta bahwa pemuda di Desa Tandung lebih memilih merantau atau bekerja di luar daerah untuk mendapatkan penghasilan lebih baik di banding bertani, mengingat lokasi Desa Tandung berada di pegunungan sehingga hasil panen kakao lebih rendah dibandingkan dengan daerah dataran dan begitupun dengan banyaknya serangan hama dan penyakit pada kakao yang susah untuk di tangani. Selain itu pekerjaan sebagai petani dianggap ketinggalan jaman tidak menghasilkan banyak uang sehingga pemuda lebih memilih bekerja di sektor lain yang berada di luar daerah.

\section{Pendidikan Formal}

Individu yang memiliki jenjang pendidikan yang tinggi cenderung untuk lebih mampu menyerap berbagai informasi yang diperoleh. Dalam prosesnya, komunikasi merupakan suatu proses sosial untuk mentranmisikan atau menyampaikan perasaan atau informasi baik yang berupa ide-ide atau gagasan-gagasan dalam rangka mempengaruhi orang lain. Adapun kategori jenjang pendidikan formal yang telah diikuti oleh responden pada saat penelitian dilakukan yaitu rendah apabila responden tidak tamat Sekolah Dasar dan tamat Sekolah Dasar (SD) atau sederajat. Sedang apabila 
Perbal: Jurnal Pertanian Berkelanjutan

Fakultas Pertanian Universitas Cokroaminoto Palopo

responden tamat Sekolah Menengah Pertama (SMP) dan tamat Sekolah Menengah Atas (SMA) atau sederajat, tinggi apabila responden tamat sarjana $(\mathrm{S} 1)$.

Berdasarkan Tabel 1, tingkat pendidikan formal petani kakao pada Kelompok Tani Limbong Dewata Kecamatan Sabbang sangat beragam. Pada tingkatan pendidikan kategori rendah yaitu tidak tamat Sekolah Dasar dan tamat Sekolah Dasar sebanyak 14 orang dengan persentase 53,8 persen, sedangkan tingkat pendidikan sedang yaitu tamat Sekolah Menengah Pertama (SMP) dan tamat Sekolah Menengah Atas (SMA) sebanyak 8 orang dengan persentase 30,8 persen, selanjutnya tingkat pendidikan tinggi yaitu tamat sarjana (S1) sebanyak 4 orang dengan persentase 15,4 persen. Sedangkan pada Kelompok Tani Rante Sipulung berada pada tingkatan pendidikan kategori rendah yaitu tidak tamat Sekolah Dasar dan tamat Sekolah Dasar sebanyak 17 orang dengan persentase 68,0 persen, sedangkan tingkat pendidikan sedang yaitu tamat Sekolah Menengah Pertama (SMP) dan tamat Sekolah Menengah Atas (SMA) sebanyak 7 orang dengan persentase 28,0 persen, selanjutnya tingkat pendidikan tinggi yaitu tamat sarjana (S1) sebanyak 1 orang dengan persentase 4,0 persen.
Deskripsi diatas dapat menujukkan bahwa di dua Kelompok Tani Limbong Dewata dan Kelompok Tani Rante Sipulung berada pada tingkat pendidikan kategori rendah tidak tamat Sekolah Dasar dan tamat Sekolah Dasar dengan persentase sebanyak masing 53 persen dan 68,0 persen. Hal ini menunjukkan bahwa masyarakat di dua kelompok tani sebagian besar merupakan masyarakat kurang mampu sehingga tidak dapat mengakses pendidikan tinggi.

\section{Pendidikan Non Formal}

Pendidikan non-formal adalah kegiatan pendidikan di luar pendidikan formal yang dapat dilaksanakan secara terstruktur dan berjenjang. Pendidikan nonformal diselenggarakan bagi masyarakat yang memerlukan layanan pendidikan yang berfungsi sebagai penggati, penambah, dan pelengkap pendidikan formal. Pendidikan non-formal berfungsi mengembangkan potensi pengetahuan, pemahaman maupun skill dari setiap orang yang mengikutinya dengan penekanan pada keterampilan fungsional serta pengembangan sikap dan kepribadian profesional. Pendidikan nonformal pada penelitian ini terkhusus pada pelatihan di bidang pertanian.

Pendidikan non-formal petani kakao Kelompok Tani Limbong Dewata di Kecamatan Sabbang di kategorikan menjadi 
tiga kategori yaitu rendah apabila petani tidak pernah atau hanya sekali mengikuti pelatihan, selanjutnya kategori sedang apabila petani mengikuti pelatihan dua sampai tiga kali pelatihan, sedangkan untuk kategori tinggi petani mengikuti pelatihan sebanyak empat sampai lima kali pelatihan.

Berdasarkan Tabel 1, petani kakao di Kelompok Tani Limbong Dewata terkait pendidikan non-formal berada pada kategori tinggi dimana sebanyak 50,0 persen anggota kelompok tani yang mengikuti pelatihan. Begitupun dengan Kelompok Tani Rante Sipulung pendidikan non-formal berada pada kategori tinggi dimana sebanyak 56,0 persen anggota kelompok tani yang mengikuti pelatihan. Hal ini menujukkan bahwa petani kakao di dua kelompok tani memiliki kesadaran dalam mengembangkan kemampuan dan keterampilanya dalam usahatani kakao, hal ini juga terkait dengan petani tidak dapat menggunakan akses media seperti internet maupun telepon genggam untuk mendapatkan informasi terkait usaha tani kakao, dikarenakan jaringan tidak dapat di akses di daerah tersebut, sehingga ketika adanya pelatihan dari lembaga pertanian, penyuluhan maupun perusahaan petani sangat antusias mengikuti pelatihan.

\section{Pengalaman Usaha Tani}

Pengalaman

berusahatani menunjukkan lamanya responden bekerja sebagai petani. Semakin petani memiliki pengalaman di dalam berusahatani, maka semakin mampu ia untuk memahami berbagai masalah yang berkaitan dengan kegiatan usahatani secara keseluruhan. Berdasarkan hasil wawancara dengan petani di wilayah penelitian, dapat diketahui bahwa pengalaman usahatani para petani tersebut sungguh beragam dimulai dari 9-40 tahun.

Pengalaman berusaha tani pada Kelomok Tani Limbong Dewata terbagi atas tiga kategori yaitu rendah 9-19 tahun sebanyak 7 orang atau 26,9 persen, sedang 20-30 tahun sebanyak 12 orang atau 40,2 persen, tinggi 31-40 tahun sebanyak 7 orang atau 26,9 persen. Sedangkan pada Keompok Tani Rante Sipulung rendah 9-19 tahun sebanyak 7 orang atau 28,0 persen, sedang 20-30 tahun sebanyak 12 orang atau 48,0 persen, tinggi 31-40 tahun sebanyak 7 orang atau 24,0 persen. Berdasarkan penjelasan diatas pengalaman berusaha tani di dua kelompok tani berada pada kategori sedang 20-30 tahun masing-masing sebanyak 12 orang atau 40,2 persen dan 12 orang atau 48, 0 persen.

Petani responden di dua kelompok penelitian sebagian besar berusahatani rata- 
Perbal: Jurnal Pertanian Berkelanjutan

Fakultas Pertanian Universitas Cokroaminoto Palopo

rata sudah 20-30 tahun. Artinya bahwa anggota kelompok tani sudah memiliki banyak pengalaman dalam berusaha tani kakao, sehingga petani tentunya dapat lebih mahir dalam mengatasi masalah yang dihadapi dalam berusaha tani kakao. Pengalaman yang cukup lama dalam berusaha tani tentunya akan mempengaruhi penguasaan inovasi dalam menjalankan usahatani kakao.

\section{Luas Lahan}

Lahan merupakan modal utama petani dalam melaksanakan usahatani, sebagai aset petani dalam menghasilkan produksi. Luas lahan yang dimiliki petani umumnya berpengaruh terhadap pendapatan (income) hasil pertanian. Lahan yang dimiliki ke dua kelompok tani cukup luas berkisar antara 1-3 hektar dan lahan yang di garap ini merupakan lahan milik pribadi. Luas lahan dalam penelitian ini terbagi atas tiga kategori, rendah apabila luas lahan 1 hektar, sedang apabila luas lahan 2 hektar dan tinggi apabila luas lahan 3 hektar.

Berdasarkan hasil penelitian, luas lahan di Kelompok Tani Limbong Dewata barada pada kategori sedang sebanyak 14 orang atau 53,8 persen orang yang memiliki luas lahan seluas 2 hektar, sedangkan petani yang memiliki luas lahan kategori sempit 1 hektar sebanyak 4 orang atau 15,4 persen.
Sedangkan pada Kelompok Tani Rante Sipulung barada pada kategori sedang sebanyak 10 orang atau 40,0 persen orang yang memiliki luas lahan seluas 2 hektar, sedangkan petani yang memiliki luas lahan kategori sempit 1 hektar sebanyak 8 orang atau 32,0 persen.

Berdasarkan penjelasan diatas luas lahan tani di dua kelompok tani berada pada kategori sedang seluas 2 hektar tahun masing-masing sebanyak 53,8 persen dan 40,0 persen. Pada umumnya semakin luas lahan yang dimiliki oleh petani maka akan memengaruhi presepsi petani untuk menggunakan inovasi, sehubungan dengan hasil penelitian Indraningsih (2011) menunjukkan bahwa luas lahan usaha tani menjadi faktor yang memengaruhi persepsi petani adopter di Kabupaten Cianjur dan Kabupaten Garut.

Masing-masing luas lahan yang dimiliki Kelompok Tani Limbong Dewata dan Kelompok Tani Rante Sipulung berada pada kategori sedang, berkisar 2 hektar. Walaupun petani sudah membudidayakan kakao sejak lama, namun mayoritas petani hanya memiliki luas lahan 1-3 hektar, ini dikarenakan wilayah tersebut terdapat aturan terkait pembukaan lahan pertanian untuk masyarakat karena sering terjadi bencana alam seperti banjir dan longsor. 
Tabel 2. Tingkat adopsi bibit kakao sambung pucuk MCC 02 Kelompok Tani Limbong Dewata dan Kelompok Rante Sipulung

\begin{tabular}{lllll}
\hline \multirow{2}{*}{ Adopsi bibit } & \multicolumn{2}{c}{ K I } & \multicolumn{2}{c}{ K II } \\
\cline { 2 - 5 } & $\mathrm{n}$ & $\%$ & $\mathrm{n}$ & $\%$ \\
\hline Rendah & 0 & 0 & 0 & 0 \\
Sedang & 3 & 11,5 & 1 & 4,0 \\
Tinggi & 23 & 88,5 & 24 & 96,0 \\
\hline Total & 26 & 100 & 25 & 100 \\
\hline
\end{tabular}

Sumber: Hasil penelitian setelah diolah, 2020

Tingkat adopsi inovasi merupakan seberapa besar petani memilih untuk menggunakan atau menolak inovasi. Di dalam proses adopsi inovasi oleh pengguna ditempuh melalui lima tahapan yaitu pengetahuan, persuasi, keputusan, implementasi, dan konfirmasi (Rogers, 2003). Pada penelitian ini ingin melihat seberapa besar petani di dua kelompok yakni Kelompok Tani Limbong Dewata dan Kelompok Tani Rante Sipulung mengambil keputusan untuk menolak atau melanjutkan inovasi bibit kakao sambung pucuk MCC 02. Tingkat adopsi inovasi bibit kakao sambung pucuk MCC 02 dilihat dari seberapa besar petani memutuskan untuk berhenti atau melanjutkan untuk menggunakan inovasi bibit kakao sambung pucuk MCC 02. Berdasarkan hasil wawancara di kedua kelompok tani menujukkan bahwa tingkat adopsi inovasi bibit sambung pucuk MCC 02 berada pada kategori tinggi, dimana sebanyak 23 orang atau 88,5 persen Kelompok Tani Limbong Dewata memilih untuk terus melanjutkan inovasi bibit kakao sambung pucuk MCC 02, sedangkan pada Kelompok Tani Rante Sipulung sebanyak 24 orang atau 96,0 persen petani memilih untuk terus melanjutkan menggunakan inovasi bibit kakao sambung pucuk MCC 02.

Petani merasa, dengan menggunakan bibit kakao sambung pucuk MCC 02 teknik sambung pucuk ini mudah untuk diterapkan, bahan-bahan yang digunakan relatif murah dan mudah untuk didapatkan, sehingga petani memilih menggunakan teknik sambung pucuk selain itu pertumbuhanya sangat baik dan sesuai dengan kondisi lahan, buah yang dihasilkan besar di banding dengan bibit lainya, buah ini juga tahan terhadap serangan hama penggerek buah dan penyakit busuk buah kakao karena mempunyai cangkang buah yang tebal dan keras. Hal ini sesuai dengan hasil penelitian (Susilo, 2017) klon MCC 02 lebih disukai oleh petani karena keunggulan daya hasil, ketahanannya terhadap penyakit VSD, penyakit busuk buah dan hama PBK. Sebagian petani lainya berada kategori sedang dimana petani raguragu untuk melanjutkan menggunakan atau tidak menggunakan inovasi bibit kakao sambung pucuk MCC 02, pada Kelompok Tani Limbong Dewata sebanyak 3 orang atau 
11,5 persen dan Kelompok Tani Rante Sipulung sebanyak 1 orang atau 4,0. Petani masih membutuhkan pertimbangan yang matang untuk tetap melanjutkan dimana petani mempunyai dua jenis tanaman kakao yaitu BR 25 dan MCC 02. Hasil dari MCC 02 lumayan baik dimana buah yang dihasilkan besar namun bijinya sedikit di bandingkan BR 25, dimana BR 25 ini meskipun buahnya kecil tapi biji yang dihasilkan banyak sehingga petani masih mempertimbangan untuk tetap melanjutkan menggunakan bibit kakao sambung pucuk MCC 02 atau tidak.

Tabel 3. Hubungan karakteristik individu dengan adopsi bibit

\begin{tabular}{clcc}
\hline \multirow{2}{*}{$\begin{array}{l}\text { No Karakteristik } \\
\text { individu }\end{array}$} & \multicolumn{2}{c}{ Adopsi bibit } \\
\cline { 2 - 3 } & & \multicolumn{1}{c}{ K I } & K II \\
\hline 1 & Umur & -0.083 & 0.227 \\
2 & $\begin{array}{l}\text { Pendidikan } \\
\text { formal }\end{array}$ & 0.021 & -0.100 \\
& & 0.023 \\
3 & $\begin{array}{l}\text { Pendidikan non } \\
\text { formal }\end{array}$ & -0.022 & $0.398^{*}$ \\
4 & $\begin{array}{l}\text { Pengalaman } \\
\text { usaha tani }\end{array}$ & $0.380^{*}$ & 0.370 \\
5 & Luas lahan & -0.384 & 0.005 \\
\hline
\end{tabular}

Keterangan: ${ }^{*}$ Korelasi signifikan pada tingkat 0.05 (2 tailed)

Sumber: Hasil penelitian setelah diolah, 2020.

\section{Hubungan Karakteristik Individu dengan Adopsi Bibit Kakao Sambung Pucuk MCC 02}

Karakteristik individu diduga berhubungan dengan adopsi bibit. Pada tabel 3 diatas menunjukkan bahwa karakteristik individu di kedua kelompok tani yang berhubungan dengan adopsi inovasi bibit kakao sambung pucuk MCC 02 adalah pengalaman usaha tani. Dapat dilihat dari hasil uji statistik menggunakan korelasi Rank Spearman yang menghasilkan koefisisen korelasi masing-masing sebesar 0,380 dan 0,398. Pengalaman usaha tani. dari kedua kelompok tersebut masuk pada kategori sedang, masing-masing sebesar 40,2 persen dan 48,0 persen, sementara itu, hasil yang ditunjukan dalam adopsi inovasi yang sebagian besar kedua kelompok tani tergolong ke dalam kategori tinggi dengan persentase masing-masing sebesar 88,5 persen dan 96,0 persen. Artinya bahwa semakin lama petani dalam menjalankan usaha taninya maka akan semakin tinggi tingkat adopsi petani.

Sementara itu indikator karakteristik individu mulai dari umur, pendidikan formal, pendidikan non formal dan luas lahan tidak berhubungan dengan adopsi bibit. Artinya bahwa tidak selamnya karakteristik individu petani memiliki hubungan yang signifikan dengan adopsi inovasi, meskipun di kedua kelompok tani memiliki karakteristik yang bervariasi namun petani tetap melakukan adopsi terhadap bibit sambung pucuk MCC 02. Karakteristik individu yang tidak memiliki hubungan yang signifikan terhadap adopsi telah ditemukan oleh beberapa 
peneliti seperti Rahma et al., (2019) hasil penelitian menunjukkan bahwa karakteristik individu mulai dari umur, tingkat pendidikan formal, tingkat pendidikan nonformal, pekerjaan utama, status lahan, luas lahan, tidak memiliki hubungan dengan perilaku petani kakao dalam menerapkan teknologi BP3T pupuk kandang. Begitupun dengan Darwis (2020) menunjukkan bahwa umur, pendidikan formal tidak memiliki hubungan yang signifikan dengan tingkat adopsi petani sistem tanam hazton.

\section{KESIMPULAN DAN SARAN}

Karakteristik individu di Kelompok Tani Limbong Dewata dan Kelompok Tani Rante Sipulung tidak jauh berbeda. Umur anggota di kedua kelompok tani mayoritas tergolong pada kategori dewasa akhir (46-55 tahun), pada pendidikan formal mayoritas tergolong pada kategori pendidikan rendah yaitu tamatan sekolah dasar (SD), sedangkan pada pendidikan non formal (pelatihan atau penyuluhan) berada pada ketegori tinggi $4-5$ kali mengikuti pelatihan. Pengalaman usaha tani mayoritas tergolong pada kategori sedang selama 20-30 tahun, sedangkan luas lahan yang dimiliki kedua kelompok tani tergolong pada kategori sedang seluas 2 hektar. Tingkat adopsi inovasi bibit kakao sambung pucuk MCC 02 di dua kelompok yaitu Kelompok Tani Limbong Dewata dan
Kelompok Tani Rante Sipulung masingmasing berada pada kategori tinggi. Karakteristik petani yang berhubungan dengan tingkat adopsi bibit adalah pengalaman usaha tani, sedangkan umur, pendidikan formal, pendidikan non formal luas lahan tidak berhubungan dengan tingkat adopsi bibit kakao sambung pucuk MCC 02.

\section{DAFTAR PUSTAKA}

Ahmad Yahya. (2016). Pengaruh karakteristik inovasi pertanian terhadap keputusan adopsi usaha tani sayuran organik. Agroscience, 6(2), 1-14.

BPS. (2019). Kabupaten Luwu Utara dalam Angka 2019. Badan Pusat Statistik Kabupaten Luwu Utara.

Darwis, K. (2020). Hubungan karakteristik sosial ekonomi petani padi dengan tingkat adopsi inovasi sistem tanam hazton di Desa Malalin Kabupaten Enrekang. Agrokompleks, 20(2), 28-35.

Fairuzia, N. (2019). Analisis status keberlanjutan perkebunan kakao rakyat di Kabupaten Luwu Utara. Institut Pertanian Bogor.

Indraningsih, K. S. (2011). Pengaruh penyuluhan terhadap keputusan petani dalam adopsi inovasi teknologi usahatani terpadu. Agro Ekonomi, 29(1), 1-24.

Indrayana, K., \& Syamsuddin. (2019). Tingkat adopsi petani terhadap paket teknologi introdusksi kakao pada kawasan perkebunan nasional di Sulawesi Barat. Agrotan, 5(2), 1-28.

Manongko, A., Pakasi, C. B. ., \& Pangemanan, L. . (2017). Hubungan karakteristik petani dan tingkat adopsi teknologi pada usahatani bawang merah di Desa Tonsewer, Kecamatan Tompaso. AgriSosioekonomi, 13(2), 35-46. 
Perbal: Jurnal Pertanian Berkelanjutan

Fakultas Pertanian Universitas Cokroaminoto Palopo

https://doi.org/10.35791/agrsosek.13.2a.

2017.16577.

Rahma, H., Wahyuni, S., Trisno, J., \& Voveriza, R. (2019). Perilaku petani dalam menerapkan teknologi BP3T (Bakteri Perakaran Pemacu Pertumbuhan Tanaman) pupuk kandang untuk tanaman kakao di Kabupaten Limapuluh Kota. Penyuluhan, 15(2), 205-216.

https://doi.org/10.25015/15201921903

Rogers, E. M. (2003). Diffusion of Innovations (5th Ed). The Free Press.

Rosyida, S. A., Sawitri, B., \& Purnomo, D. (2021). Hubungan karakteristik petani dengan tingkat adopsi inovasi pembuatan bokashi dari limbah ternak sapi. Kirana, 2(1), 54-64.

Sitanggang, L., Lubis, S. N., \& Kusuma, S. I. (2014). Tingkat adopsi petani terhadap penggunaan pupuk sesuai dosis anjuran pada usahatani padi sawah (Studi Kasus: Desa Sidoarjo Dua Ramunia, Kecamatan Beringin, Kabupaten Deli Serdang) Lasdiman. Agriculture and Agribusiness Socioeconomics, 3(4), 115.

Susilo, A. W. (2017). Strategi pengembangan bahan tanam kakao. Warta Pusat Penelitian Kopi dan Kakao Indonesia, 29(3), 1-7.

Syakir, M. (2016). Pemantapan inovasi dan diseminasi teknologi dalam memberdayakan petani. Prosiding Seminar Nasional Perlindungan dan Pemberdayaan Pertanian dalam Rangka Pencapaian Kemandirian Pangan Nasional dan Peningkatan Kesejahteraan Petani, 3-14. http://pse.litbang.pertanian.go.id/ind/pdf files/prosiding_2016/0_1.pdf. 